\title{
Mineralogical and Geochemical Control of Altered Andesitic Tuff upon Debris Slide Occurences at Pelangan Area, Southern Mountain of Lombok Island, Indonesia
}

\author{
Dwi Winarti ${ }^{* 1}$, Dwikorita Karnawati ${ }^{2}$, Hary Christady Hardiyatmo ${ }^{3}$, and Srijono ${ }^{2}$ \\ ${ }^{1}$ Department of Mining Engineering, Muhammadiyah Mataram University, Indonesia \\ ${ }^{2}$ Department of Geological Engineering, Gadjah Mada University, Yogyakarta, Indonesia \\ ${ }^{3}$ Department of Civil and Environmental Engineering, Gadjah Mada University, Indonesia
}

\begin{abstract}
Debris slides were recently found in the Pelangan area at Southern Mountain of Lombok Island, Indonesia. Pelangan is well known as the gold mineralization and hydrothermal alteration area. This study is aimed to identify the mineralogy and geochemistry of altered andesitic tuff that controlled slope instability and induced debris slides. For this purpose, it is necessary to prepare the field observation and laboratory analyses. Landslide inventory reveals that the Pelangan debris slides mostly occur in altered andesitic tuff. Based on the outcrop observations in the field, andesitic tuff found around the Pelangan debris slides have been altered in general. The strong intensity of alteration developed by hydrothermal alteration in this study area produces large amount of clay minerals especially montmorillonite, kaolinite, and illite. The abundance of those clay minerals reflect the intermediate argillic alteration. Montmorillonite is a type of clay mineral that easily swells at wet condition and easily shrinkages at dry condition. Swelling of clay mineral destroys intersheet and interlayer bonds, and reduces shear strength. The presence of clay minerals in the altered andesitic tuff of intermediate argillic zone can be considered as one of the factors that induced to the Pelangan debris slides. Further studies on geotechnical and slope stability analysis of the landslide area are crucial to be done for better understanding of the characteristics of the altered rocks inducing hazardous landslides.
\end{abstract}

Keywords: Clay mineral · Shear strength $\cdot$ Hydrothermal alteration · Debris slide $\cdot$ Lombok Island · Indonesia.

\section{INTRODUCTION}

Landslide is one of the most common types of natural disaster in tropical countries such as Indonesia, especially on the mountainous and hilly terrain with complex geological condition. Geology, topography, slope hydrology, material properties, climate, landuse condition, infiltration, seismicity, and human activity are several factors which significantly affect landslides (Abramson et al., 1996, Karnawati, 2005, Hardiyatmo, 2006). According to Cruden and Varnes (1993) after Abramson et al. (1996) there

\footnotetext{
${ }^{*}$ Corresponding author: D. WINARTI, Department of Mining Engineering, Muhammadiyah Mataram University, Indonesia. E-mail: winarti.dwiyk@gmail.com
}

are five main types of landslide, namely fall, topple, slide, spread, and flow. The first two types are features frequently associated with rock slopes, whereas the latter three are related to soil slopes (Abramson et al., 1996).

Lombok Island is one of areas in Indonesia that experiences landslides. Most landslides frequently occur in areas intensively suffered by mineralization and hydrothermal alteration including Pelangan area at Southern Mountain of Lombok Island. The studied landslide is situated in Pelangan area, Sekotong District, West Lombok, in the southwest part of Lombok Island, Indonesia. Geographically, this area is located in zone 50 S UTM, from $381000 \mathrm{mE}$ - 
$386000 \mathrm{mE}$ and $9024000 \mathrm{mN}-9032000 \mathrm{mN}$, having $40 \mathrm{~km}^{2}$ area (Figure 1). The major town close to the study area is Mataram, $54 \mathrm{~km}$ to the southwest. Pelangan area is characterized by strongly hydrothermal altered rocks, flat to very steep slopes, complex geological structures, low intensity rainfall, and less density vegetation. This area has different morphologies that the slope degree varies from $0^{\circ}$ to $88^{\circ}$ and the elevation varies from 0 to 394 meters above sea level. The moderate to very steep slope $\left(15^{\circ}-88^{\circ}\right)$ occupy $71,59 \%$ of the total area, whereas $28,41 \%$ is flat to gentle slope (less than $15^{\circ}$ ). This condition is prone to landslide.

Winarti et al. (2016a) investigated landslides at Pelangan, Sekotong, in West Lombok. Rock falls, debris slides, and a creep have been recognized. Debris slides were the most frequent landslides. These landslides occuring on the periode of September 2013 to January 2014. Debris slide is a down-slope movement of a mass of soil, or soil and rock fragments, moving as a unit or a number of units along a steeply dipping planar surface (Hunt, 2007). In the Pelangan area, the debris slides have close relationship with hydrothermal alteration. The hydrothermal alteration produced clay minerals and reduced the shear strength of rocks. Consequently, it tend to landslide in Pelangan area.

Furthermore, there is no advance studies that describes the mineralogical and geochemical control of altered andesitic tuff upon Pelangan debris slide occurrences. Therefore, this paper focuses on identifying mineralogical and geochemical characteristics of altered andesitic tuff that would be potentially reducted the shear strength and induced the debris slide occurrences at Pelangan area.

\section{Methods}

This study was conducted by literature search, field observation, laboratory work, and analyses. Field observation includes landslide inventory, surface geological mapping, hydrothermal alteration mapping, and sampling of altered andesitic tuff. Laboratory work includes petrography, X-Ray Diffraction (XRD), Scanning Electron Microscopy (SEM), and X-Ray Fluorescene (XRF) analyses of a total of 36 samples. Petrography and XRD analyses were conducted at Department of Geological Engineering, Faculty of
Engineering, Gadjah Mada University, whereas SEM and XRF analyses were carried out in the tekMIRA laboratory of Research and Development Centre for Mineral and Coal Technology, Bandung, Indonesia.

\section{Results And Discussion}

\section{Geology}

Lombok Island is located in the central part of the Sunda-Banda magmatic arc. This magmatic arc is a result of three major tectonic plates convergent between the Indo-Australian Plate, the Eurasian Plate, and the Pacific Plate in lateMiocene (Hamilton, 1979). Physiographically, Lombok Island can be differentiated into three geologic terrains, namely Northern Mountain Zone, Southern Mountain Zone, and flat terrain in the middle part of the island. Tertiary rocks are exposed in the Southern Mountain Zone.

The regional stratigraphy of the study area comprises the volcanic and sedimentary rocks, which is of Late Oligocene to Late Miocene (Suratno, 1994). The oldest rock unit in this region is Pengulung Formation (Tomp) which composed of breccia, lava, tuff, and limestone lenses containing of sulphide minerals and quartz veins. This formation interfingering by the Kawangan Formation (Tomk), it consists of sandstone, claystone, and breccia. Both of those formations were cross-cut by Middle Miocene andesite porphyry, diorite, and dacite intrusions. The intrusions produces ore mineralization and hydrothermal alteration. The Pengulung and Kawangan Formation unconformably overlain by Late Miocene calcarenite limestone locally crystalized of Ekas Formation (Tme). The youngest deposit of the Pelangan area which is Holocene sedimentation (Qa) has been represented by alluvium and coral reef deposits on coastal and lowland plains.

The stratigraphy of the Pelangan area is consist of andesitic breccia, andesitic tuff, andesite porphyry, diorite, dacite, limestone, and alluvium (Figure 3). Andesitic breccia is the oldest rock in the Pelangan area. Meanwhile, andesitic tuff is the most widespread covered rock and occupied $63,12 \%$ of the total study area. Andesitic breccia and andesitic tuff are regarded as the member rock of Pengulung Formation. These rocks suffers intensive hydrothermal alteration. The andesite porphyry, 


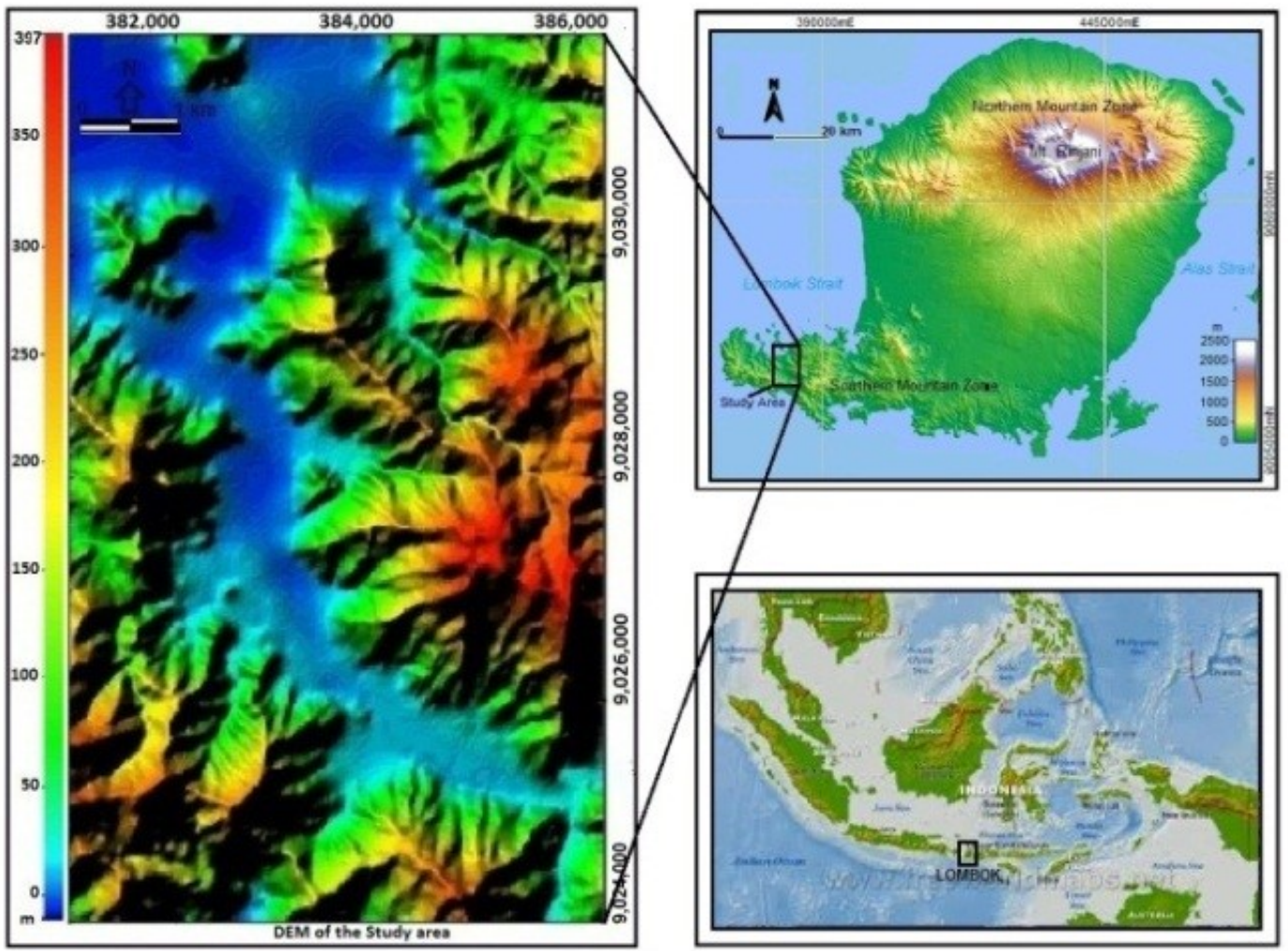

Figure 1: Location map of Pelangan area, Sekotong District, West Lombok, Indonesia.

diorite, and dacite intrusions are interpreted to be source of mineralization and hydrothermal alteration process. Many landslides and vulnerable sites are common to be found in the Pelangan area which composed of hydrothermal altered rocks of Pengulung Formation. According to the AHP analysis, hydrothermal alteration and slope inclination are the most important factor controlling landslide occurrences within Pelangan area (Winarti et al., 2016b).

\section{Hydrothermal alteration}

Pelangan has experienced landslides. The landslides generally occur in hydrothermal altered rocks of Pengulung Formation. The andesite porphyry, diorite, and dacite intrusions are interpreted as source of mineralization and hydrothermal alteration process. Andesitic breccia and andesitic tuff were cross-cut by those intrusions produced hydrothermal alteration zones. The types of hydrothermal alteration are well exposed. In this study, the mineral assemblages of Evans (1993) are applied to clasify the hydrothermal alteration type. On the basis of mineral assemblages, two main alteration zones are identified including propylitic and intermediate argillic alteration (Figure ?? and Table 1).
Propylitic alteration characterized by chlorite, epidote, albite, dolomite, calcite, ankerite, and accessories minerals include montmorillonite, illite, quartz, pyrite, and magnetite, whereas intermediate argillic alteration typified by montmorillonite, kaolinite, and accessories minerals include illite, quartz, pyrite, and magnetite. The debris slides occured in Pelangan area is related to intermediate argillic alteration (S04, S07, S08, S12, S13, S15, and S16).

\section{Mineralogy}

Totally seven debris slides were recognized in the study area. Fieldwork observation shows that the Pelangan debris slides mostly occured in altered andesitic tuff (Figure 4). In megascopic, the altered andesitic tuff is greenish white to yellowish white in colour, very fine to very coarse grain size ( 0.003 to $64 \mathrm{~mm}$ ), and composed of andesite, quartz, biotite, clay, and pyrite. Generally, the altered andesitic tuff can easily crushed by hand. Petrographic analysis have done on seven samples of altered andesitic tuff that represent each debris slides. Results show that the altered andesitic tuff consists of plagioclase $(10 \%)$, clinopyroxene $(5 \%)$, quartz $(10-20 \%)$, and secondary minerals $(80-95 \%)$ 
Table 1: Mineral assemblages of hydrothermal alteration zone in the Pelangan area.

\begin{tabular}{|c|c|c|c|}
\hline \multirow{2}{*}{ Zone } & \multirow{2}{*}{ Location } & \multicolumn{2}{|c|}{ Mineral Assemblage } \\
\hline & & Key Mineral & Accessory Mineral \\
\hline \multirow{4}{*}{ Propylitic } & S01 & $\begin{array}{l}\text { Chlorite, epidote, albite, } \\
\text { calcite, ankerite }\end{array}$ & $\begin{array}{l}\text { Montmorillonite, illite, quartz, } \\
\text { pyrite, magnetite }\end{array}$ \\
\hline & S05 & $\begin{array}{l}\text { Chlorite, epidote, calcite, } \\
\text { ankerite, dolomite }\end{array}$ & Illite, quartz, pyrite, magnetite \\
\hline & S11 & $\begin{array}{l}\text { Chlorite, epidote, albite, } \\
\text { calcite, dolomite }\end{array}$ & $\begin{array}{l}\text { Montmorillonite, illite, quartz, } \\
\text { pyrite, magnetite }\end{array}$ \\
\hline & S17 & Chlorite, albite, calcite & Montmorillonite, illite, quartz \\
\hline \multirow{11}{*}{$\begin{array}{l}\text { Intermediate } \\
\text { Argillic }\end{array}$} & S04 & Montmorillonite, kaolinite & Illite, quartz, pyrite, magnetite \\
\hline & S07 & Montmorillonite, kaolinite & Illite, quartz, pyrite, magnetite \\
\hline & S08 & Montmorillonite, kaolinite & Illite, quartz, pyrite \\
\hline & S09 & Montmorillonite, kaolinite & Illite, quartz, pyrite \\
\hline & S10 & Montmorillonite, kaolinite & Illite, quartz, pyrite, magnetite \\
\hline & S12 & Montmorillonite, kaolinite & Illite, quartz, pyrite \\
\hline & S13 & Montmorillonite, kaolinite & Illite, quartz, pyrite \\
\hline & S15 & Montmorillonite, kaolinite & Illite, quartz, pyrite, magnetite \\
\hline & S16 & Montmorillonite, kaolinite & Illite, quartz, pyrite, magnetite \\
\hline & S18 & Montmorillonite, kaolinite & Illite, quartz, pyrite, magnetite \\
\hline & S20 & Montmorillonite, kaolinite & Illite, quartz, pyrite, magnetite \\
\hline
\end{tabular}




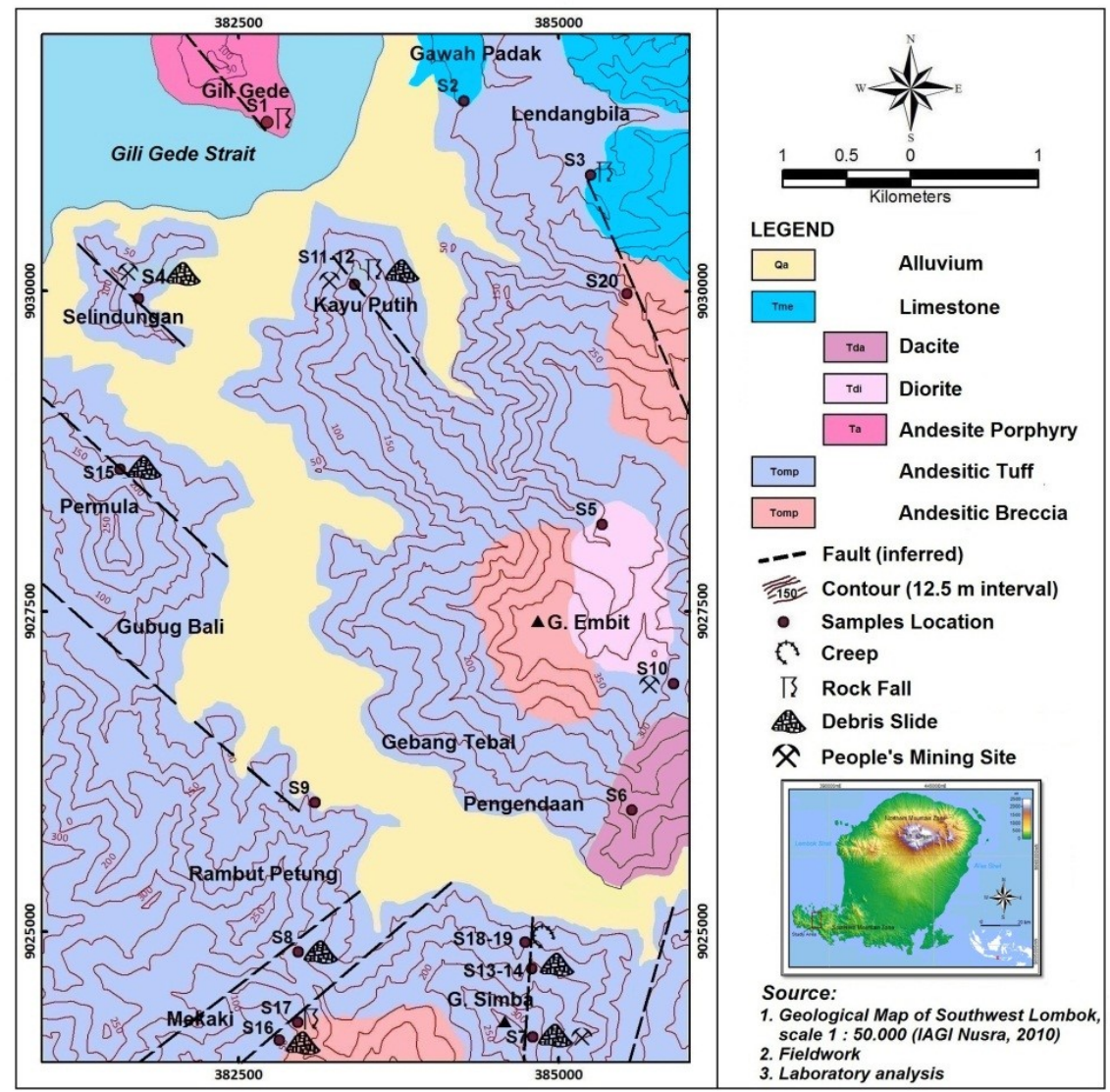

Figure 2: Geological map of Pelangan area (modified from Suratno, 1994, fieldwork observation).

include chlorite, smectite, muscovite, opaque minerals, and iron oxides with size less than 0.1 to $1.0 \mathrm{~mm}$ (Figure 5). Based on the classsification of alteration intensity of Kingston Morrison (1996) as shown in Table 2, this altered andesitic tuff is classified as strongly altered (more than 75\%). SEM images of altered andesitic tuff shows that kaolinite is found in the form of hexagonal and rolled plate, and quartz exist in the form of flake, cube, and rossete (Figure 6). Based on XRD analysis, seven samples of the altered andesitic tuff contain montmorillonite, kaolinite, illite, quartz, pyrite, and magnetite (Figure 7). According to Evans (1993) those minerals are well developed in intermediate argillic alteration.

\section{Geochemistry}

Whole-rock geochemistry data were assessed to determine chemical changes associated with the alteration intensity. In this study, major element compositions of the altered andesitic tuff samples were analysed by XRF method. Results of geochemical analyses of altered andesitic tuff are reported in Table 3 and Figure 8 . The $\mathrm{SiO}_{2}$ contents range from 56.68 to $85.11 \mathrm{wt} . \%$, with an average of $67.399 \mathrm{wt} . \%$, and the $\mathrm{Al}_{2} \mathrm{O}_{3}$ contents range from 8.83 to $22.66 \mathrm{wt}$.\%, averaging 16.126 wt.\%. The $\mathrm{Fe}_{2} \mathrm{O}_{3}$ contents range from 0.97 to $14.62 \mathrm{wt} . \%$, averaging $6.446 \mathrm{wt} . \%$, and the $\mathrm{MnO}$ concentrations range from 0.003 to $0.049 \mathrm{wt} . \%$, with an average of $0.014 \mathrm{wt} . \%$. The $\mathrm{MgO}, \mathrm{CaO}$, $\mathrm{Na}_{2} \mathrm{O}$, and $\mathrm{K}_{2} \mathrm{O}$ contents ranges from 0.029 to 1.42 wt. $\%, 0.04$ to 0.26 wt. $\%, 0.018$ to 0.26 wt.\%, and 0.44 to 6.14 wt.\%, averaging 0.636 wt.\%, 0.117 wt. $\%, 0.086$ wt. $\%$, and 3.006 wt. $\%$, respectively. The $\mathrm{TiO}_{2}$ concentrations range from 0.22 to $1.04 \mathrm{wt} \%$ and averages $0.67 \mathrm{wt} \%$. The $\mathrm{P}_{2} \mathrm{O}_{5}$ content ranges between 0.013 to $0.18 \mathrm{wt} . \%$ and averages 0.089 wt.\%, whereas LOI concentrations vary from 2.48 to 8.04 wt.\%, with and average $5.296 \mathrm{wt} . \%$. The AI concentrations range from 88.324 to 97.574 and averages 93.688 .

Ishikawa et al. (1976) quoted by Gifkins (2001) and Large et al. (2001) could be used to study alteration intensity of altered volcanic and sedimentary rocks. The alteration intensity (AI) is given by:

$$
A I=\frac{100\left(\mathrm{~K}_{2} \mathrm{O}+\mathrm{MgO}\right)}{\left(\mathrm{K}_{2} \mathrm{O}+\mathrm{MgO}+\mathrm{Na}_{2} \mathrm{O}+\mathrm{CaO}\right)}
$$




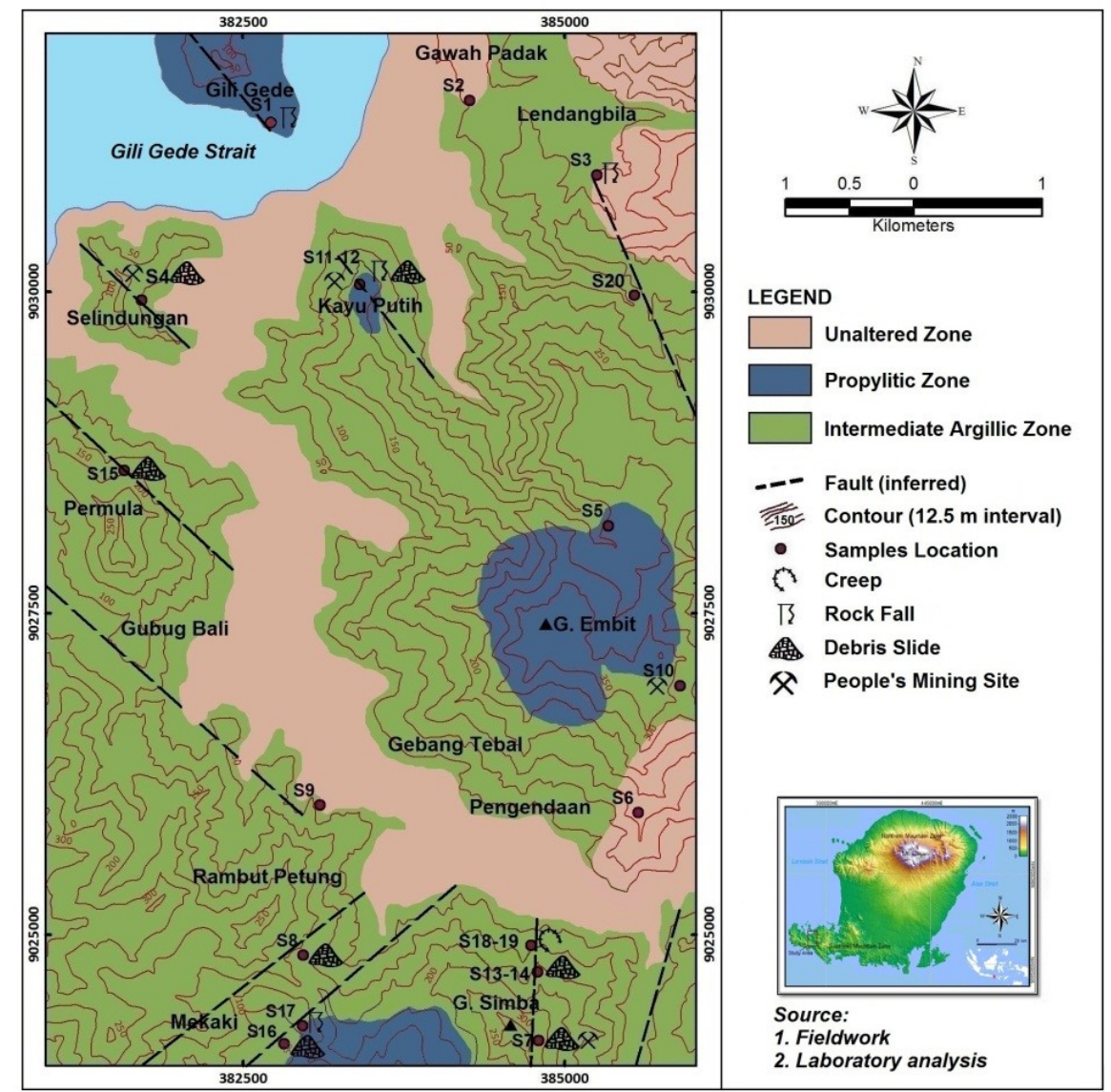

Figure 3: Hydrothermal alteration zone map of Pelangan area.
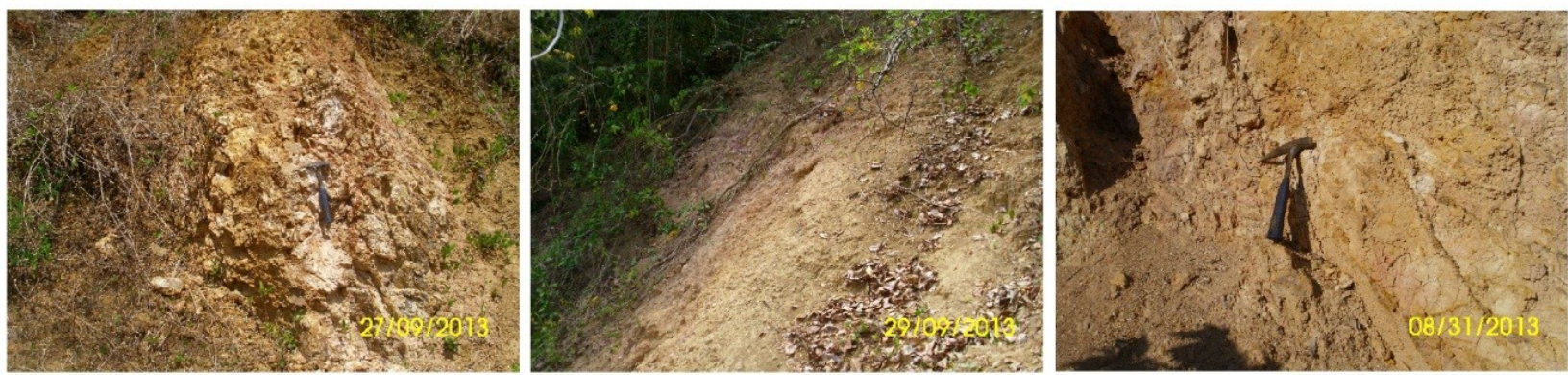

Figure 4: Outcrop of altered andestic tuff, located on the Pelangan debris slide S8 (left), S13 (middle), and S16 (right).
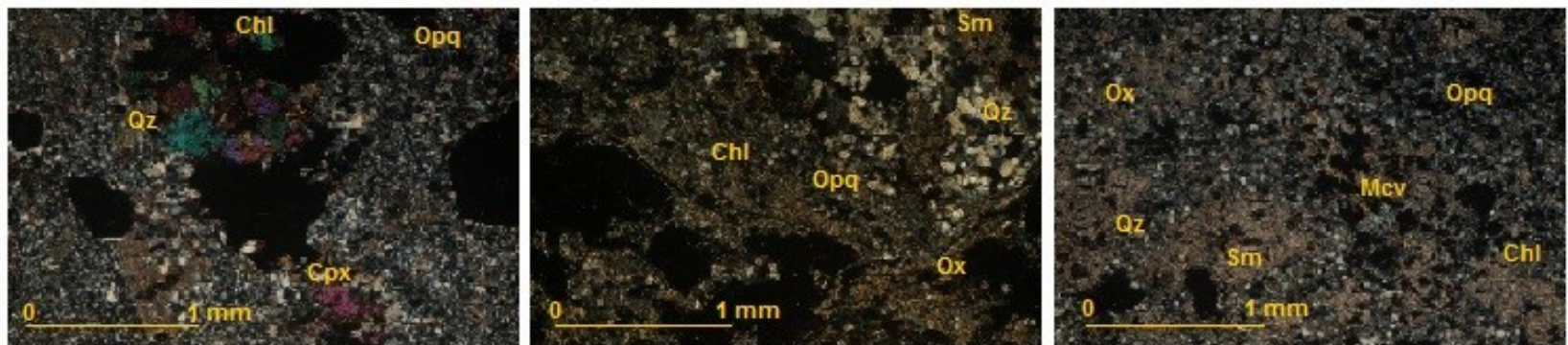

Figure 5: Optical photomicrographs of altered andesitic tuff showing the presence of clinopyroxene (Cpx), quartz (Qz), opaque mineral (Opq), chlorite (Chl), smectite (Sm), iron oxides (Ox), and muscovite (Mcv). 
Table 2: Classification of alteration intensity (Kingston Morrison, 1996).

\begin{tabular}{|l|l|}
\hline \multicolumn{1}{|c|}{$\begin{array}{c}\text { Intensity } \\
\text { of alteration }\end{array}$} & \multicolumn{1}{c|}{ Percentage of secondary mineral } \\
\hline Unaltered & No secondary minerals \\
\hline Weakly altered & Less than 25 volume \% secondary minerals \\
\hline Moderately altered & 25-75 volume \% secondary minerals \\
\hline Strongly altered & More than 75 volume \% secondary minerals \\
\hline Intensely altered & $\begin{array}{l}\text { Completely altered (except for primary quartz, zircon, and apatite), but } \\
\text { primary textures remain visible }\end{array}$ \\
\hline Totally altered & $\begin{array}{l}\text { Completely altered (except for primary quartz, zircon, and apatite), but } \\
\text { primary textures loss }\end{array}$ \\
\hline
\end{tabular}
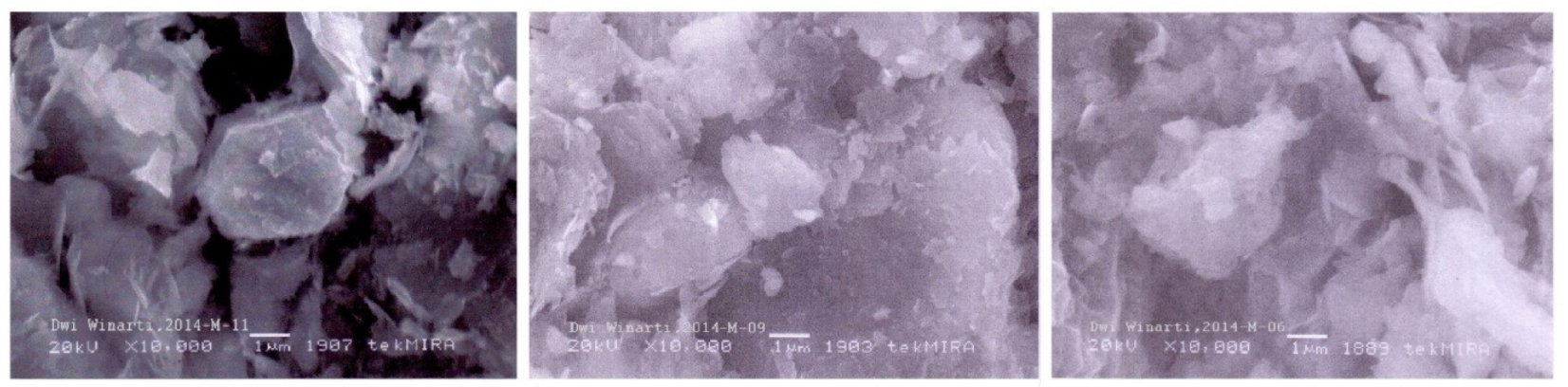

Figure 6: SEM images of altered andesitic tuff showing the presence of hexagonal plate of kaolinite and rossete of quartz (left), flake of kaolinite (middle), and flake of quartz and rolled plate of kaolinite (right).
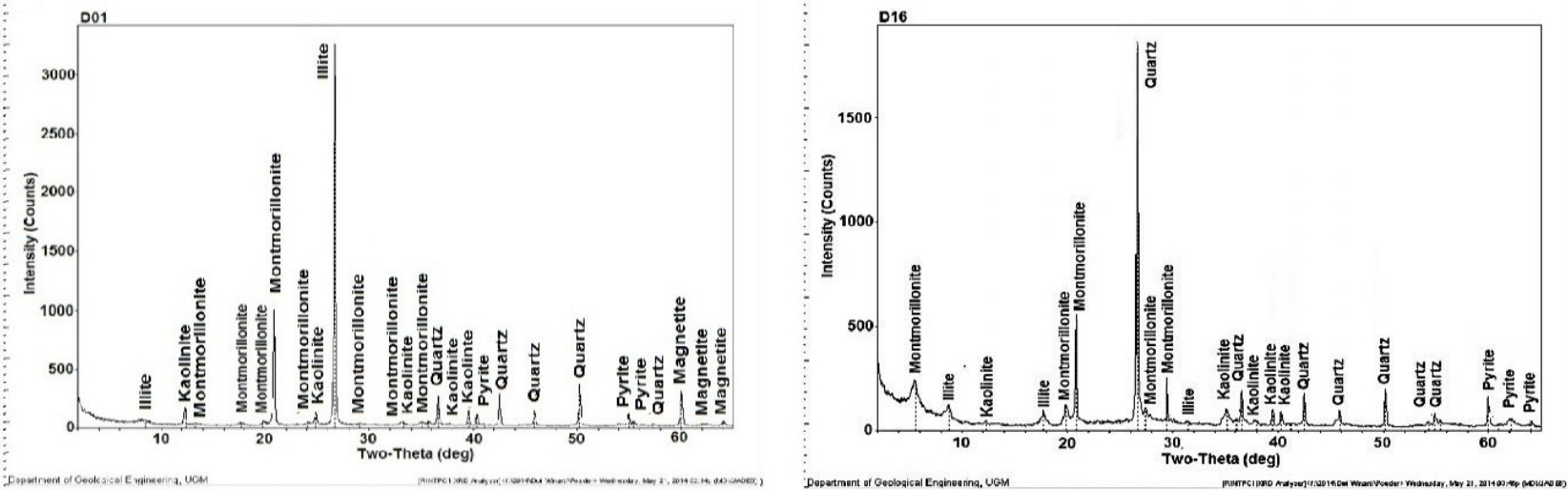

Figure 7: X-Ray Diffraction patterns of altered andesitic tuff from the Pelangan area. 
Table 3: Geochemical analyses of altered andesitic tuff for calculating hydrothermal alteration intensity (major elements in weight $\%$ and determined by XRF).

\begin{tabular}{|l|r|r|r|r|r|r|r|r|}
\hline Sample & S04/F01 & \multicolumn{1}{|c|}{ S07/F11 } & S08/F09 & S12/F10 & \multicolumn{1}{|c|}{ S13/F13 } & S15/F03 & S16/F16 & Average \\
\hline $\mathrm{SiO}_{2}$ & 85.110 & 63.070 & 59.650 & 56.720 & 56.680 & 80.510 & 70.050 & 67.399 \\
$\mathrm{Al}_{2} \mathrm{O}_{3}$ & 10.170 & 22.660 & 21.650 & 16.740 & 20.050 & 8.830 & 12.780 & 16.126 \\
$\mathrm{Fe}_{2} \mathrm{O}_{3}$ & 1.380 & 0.970 & 6.370 & 14.620 & 8.950 & 4.300 & 8.530 & 6.446 \\
$\mathrm{MnO}$ & 0.003 & 0.019 & 0.007 & 0.008 & 0.049 & 0.007 & 0.008 & 0.014 \\
$\mathrm{MgO}$ & 0.029 & 1.100 & 0.430 & 0.470 & 1.420 & 0.460 & 0.540 & 0.636 \\
$\mathrm{CaO}$ & 0.044 & 0.040 & 0.160 & 0.260 & 0.160 & 0.065 & 0.087 & 0.117 \\
$\mathrm{Na} 2$ & 0.018 & 0.140 & 0.019 & 0.092 & 0.260 & 0.030 & 0.046 & 0.086 \\
$\mathrm{~K}_{2} \mathrm{O}$ & 0.440 & 6.140 & 3.280 & 2.580 & 3.310 & 2.220 & 3.070 & 3.006 \\
$\mathrm{TiO}_{2}$ & 0.220 & 0.010 & 1.040 & 0.790 & 0.780 & 0.360 & 0.490 & 0.670 \\
$\mathrm{P}_{2} \mathrm{O}_{5}$ & 0.045 & 0.013 & 0.110 & 0.150 & 0.180 & 0.063 & 0.063 & 0.089 \\
$\mathrm{LOI}$ & 2.480 & 4.770 & 7.160 & 7.420 & 8.040 & 2.950 & 4.250 & 5,296 \\
$\mathrm{Total}$ & 99.939 & 99.932 & 99.876 & 99.850 & 99.879 & 99.795 & 99.914 & 99.884 \\
\hline $\mathrm{AI}$ & 88.324 & 97.574 & 95.397 & 89.653 & 91.845 & 96.577 & 96.447 & 93.688 \\
\hline
\end{tabular}

$\mathrm{LOI}=$ Loss on Ignition, $\mathrm{AI}=$ Alteration intensity $=100 \mathrm{x}\left(\mathrm{K}_{2} \mathrm{O}+\mathrm{MgO}\right) /\left(\mathrm{K}_{2} \mathrm{O}+\mathrm{MgO}+\mathrm{Na}_{2} \mathrm{O}+\mathrm{CaO}\right)$
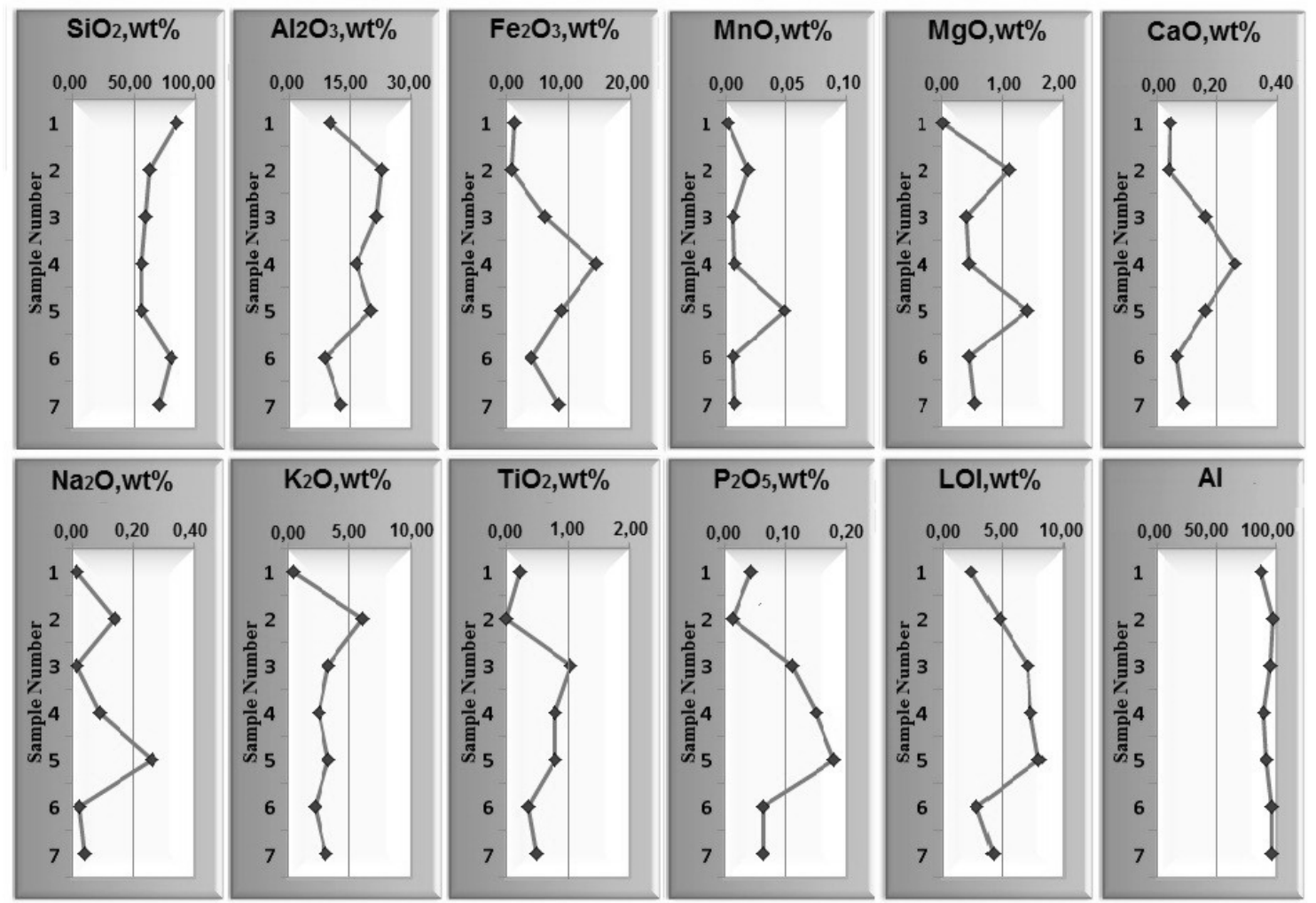

Figure 8: Vertical variations in the geochemical composition and alteration intensity of altered andesitic tuff. 
Table 4: Alteration intensity classification (Ishikawa et al., 1976 after Gifkins, 2001).

\begin{tabular}{|l|c|}
\hline \multicolumn{1}{|c|}{$\begin{array}{c}\text { Intensity of } \\
\text { alteration }\end{array}$} & $\begin{array}{c}\text { Values of chemical } \\
\text { change }\end{array}$ \\
\hline Unaltered & $<25$ \\
Weakly altered & $25-70$ \\
Strongly altered & $>70$ \\
\hline
\end{tabular}

To classify alteration intensity, this study adopted the classification of alteration intensity $(A I)$ based on chemical changes as shown in Table 4

The alteration intensity for the majority of the altered andesitic tuff vary from 88.324 to 97.574 . Based on the classification of alteration intensity (Table 4), the altered andesitic tuff in the intermediate argillic zone is classified as strongly altered.

\section{Implication for debris slide}

Pelangan area, southwestern part of Lombok Island, is well known as the area of gold mineralization and hydrothermal alteration. The study area is consisted of Tertiary volcanic and sedimentary rocks of Pengulung Formation (Tomp) that altered due to hydrothermal alteration. The hydrothermal altered rocks consists of andesitic breccia, andesitic tuff, andesite porphyry, and diorite. Most of the landslides frequently occured in this area is debris slides. And it is mostly due to the altered andesitic tuff.

On the basis of mineral assemblages (Evans, 1993), hydrothermal alteration in Pelangan area was developed by two main alteration zones consisting of propylitic and intermediate argillic alteration. The propylitic alteration zone is developed in the andesitic breccia, andesitic tuff, andesite porphyry, and diorite, whereas the intermediate argillic zone is composed of andesitic breccia and andesitic tuff. The area within intermediate argillic alteration is subjected to an intensive debris slides occurences in the study area. Applying classification of alteration intensity based on percentage of secondary minerals of Kingston Morrison (1996), and chemical changes of Ishikawa et al. (1976) quoted by Gifkins (2001), the altered andesitic tuff in the intermediate argillic zone is classified as strongly altered.

The strong intensity of alteration developed by hydrothermal alteration in this study area produces large amount of clay minerals especially montmorillonite and kaolinite, with few illite, quartz, pyrite, and magnetite. Montmorillonite is a type of clay mineral that easily swells at wet condition and easily shrinkages at dry condition (Pusch and Yong, 2006). Swelling of clay mineral destroys intersheet and interlayer bonds, and consequently the shear strength of altered andesitic tuff tend to decrease and prone to landslide. The presence of abundant montmorillonite in the altered andesitic tuff of intermediate argillic zone can be considered as one of the factors that induced to the Pelangan debris slides.

\section{CONCLUSION}

The Pelangan debris slides generally occur in altered andesitic tuff of Pengulung Formation (Tomp). On the basis of mineral assemblages, percentage of secondary minerals, and chemical changes, and by comparison with existing models of Evans (1993), Kingston Morisson (1996) and Ishikawa et al. (1976) quoted by Gifkins (2001), respectively, it concluded that the debris slides occured in the study area is related to montmorillonite as a product of intermediate argillic alteration with strong intensity. The presence of abundant montmorillonite in the altered andesitic tuff is considered as one of factors that induced the debris slide, because it has the property of swelling and reducing shear strength at wet condition.

\section{ACKNOWLEDGEMENTS}

This research was supported by Muhammadiyah Mataram University. We would like to thank students of the Mining Engineering Department, Muhammadiyah Mataram University for their help during the field observation. We are thankful to the Government of West Lombok Regency, which has given permission to do research in the Pelangan area.

\section{REFERENCES}

Abramson, L.W., Lee, T.S., Sharma, S., and Boyce, G.M. (1996) Slope stability and methods. John Wiley and Sons, Inc. New York. 629 pp. 
Evans, A.M. (1993) Ore geology and induatrial minerals. Third Edition, Blackwell Scientific Publications, London, 390 pp.

Gifkins, C.C. (2001) Textural and chemical characteristics of diagenetic and hydrothermal alteration in glassy volcanic rocks: examples from the Mount Read Volcanics, Tasmania. Journal of Economic Geology. 96: 973-1002.

Hamilton, W. (1979) Tectonics of the Indonesian region. USGS Professional Paper, 1078, 345 pp.

Hardiyatmo, H.C. (2006) Penanganan tanah longsor dan erosi. Edisi Pertama, Gadjah Mada University Press, Yogyakarta, 450 pp.

Hunt, R.E. (2007) Geologic Hazard A Field Guide for Geotechnical Engineering. CRC Press, Boca Raton, $323 \mathrm{pp}$.

Karnawati, D. (1996) Mechanism of Rain-Induced Landsliding in Allophanic and Halloystic Soils in Java. Ph.D Tesis, unpublished thesis The University of Leeds, 230 pp.

Karnawati, D. (2005) Bencana alam gerakan massa tanah di Indonesia dan upaya penanggulangannya. Department Geological Engineering, Engineering Faculty, Gadjah Mada University, Yogyakarta, $232 \mathrm{pp}$.

Kingston Morisson. (1996) Magmatic-realated hydrothermal system. Short Course Manual, Kingstone Morisson, Australia, 73 pp.
Large, R.R., Gemmell, J.B., Paulick, H., and Huston, D.L. (2001) The alteration box plot: a simple approach to understanding the relationship between alteration mineralogy and lithogeochrmistry associated with volcanic-hosted massive sulfide deposits. Journal of Economic Geology. 96: 957-971.

Pusch, R., and Yong R.N. (2006) Microstructure of smectite clays and engineering performance. Taylor and Francis, London, 328 pp.

Suratno, N. (1994) Geological and mineral potential map of West Nusa Tenggara. Lombok and Sumbawa quadrangles, scale 1:250.000, Mataram: Branch Office of Department Of Mines and Energy West Nusa Tenggara Province.

Winarti, D., Srijono, Hardiyatmo, H.C., and Karnawati, D. (2016a) Mineralogical characteristics of landslide-induced hydrothermal altered rocks at Southern Mountain slope of Lombok Island, Indonesia. Paper presented on The 6th Annual Basic Science International Conference, Indonesia.

Winarti, D., Srijono, Hardiyatmo, H.C., and Karnawati, D. (2016b) GIS-Based Landslide Susceptibility Mapping by Using Analytical Hierarchy Process in The Hydrothermally Altered Area at Southern Mountain of Lombok Island, Indonesia. Journal of Kurvatek, 1(1). 